\title{
Trendi spreminjanja pretokov slovenskih rek
}

\section{Florjana Ulaga}

Ministrstvo za okolje, prostor in energijo, Agencija RS za okolje, Vojkova 1b, 1000 Ljubljana, Slovenija

e-mail: florjana.ulaga@gov.si

\section{Izvleček}

Glede na podnebne spremembe predvidevamo, da se količina vode v porečjih zmanjšuje in da se spreminjajo predvsem ekstremna hidrološka stanja. Analiza 45 letnega niza pretokov rek, padavin in gladin podzemnih vod, pa predvidevanj ni v celoti potrdila. Poleg klimatskih sprememb moramo za presojo spreminjanja dejanskih količin vode upoštevati tudi vpliv evapotranspiracije, poraščenosti z gozdom in spreminjanje naravnih površin v kmetijska ter urbana območja.

Ključne besede: odtok, pretok, podnebne spremembe, trend, vodozbirno zaledje.

\section{Trends in discharge changes of slovenian rivers}

\begin{abstract}
Our estimation, based on the observed climatic changes, that the quantity of water in river basins is in decrease and that the changes are particularly manifest in extreme hydrological situations has not been fully confirmed by the analysis of the data on river discharges, precipitation and water tables over the period of 45 years. In assessing changes in the actual amounts of water it is necessary to take into account, in addition to climatic changes, also the impact of evapotranspiration, forest cover, and transformation of natural landscape to agrarian and urban areas.
\end{abstract}

Key words: runoff, discharge, climate changes, trend, catchment area. 


\section{UVOD}

Čas je v hidrološkem smislu eden od bistvenih komponent pri analiziranju hidroloških stanj. $\mathrm{V}$ določenih primerih je pomembnih že nekaj sekund, v nasprotnem primeru pa se dogodki odvijajo počasi in lahko govorimo o tisočih letih, ki resnično vplivajo na hidrološko stanje. Če se osredotočimo na vodo površinskih vodotokov, lahko govorimo o povprečnem hidrološkem času 1060 dni, za uskladitev pritoka in odtoka določenega območja. In ker poteka zbiranje hidroloških podatkov na nivoju dnevnih oziroma urnih pretokov, lahko za osnovo hidrološkega raziskovanja prevzamemo ravno srednjeročen hidrološki ciklus.

Padavine, ki padejo na porečje, napolnilo zaledje rečnih izvirov in s tem povečajo pretok v rečnem koritu ter pospešijo odtok iz porečja. Kako hitro nastopi visok vodni val je odvisno od intenzivnosti padavin in velikosti ter značilnosti porečja. Pri teh stopajo v ospredje infiltracija, zaloge podpovršinske vode in hitrost odtoka. Čas v katerem voda iz določenega območja porečja odteče je odvisen od hitrosti vodnega toka $v$ rečnem koritu in od hitrosti odtoka v zaledju, torej na celem vodozbirnem območju.

Medtem ko je pri kratkoročnih in srednjeročnih hidroloških pojavih v ospredju površinski odtok, je $\mathrm{v}$ daljših hidroloških periodah pomembno podzemno pretakanje vode. Povprečna hitrost podzemnega pretoka je meter/dan ali meter/leto. To pa pomeni zakasnitveni čas najmanj nekaj let, celo v manjših porečjih. Vseeno še vedno ostaja vprašanje v kolikšni meri je podtalnica poglavitna komponenta vpliva na visoke rečne valove, saj je pronicanje vode skozi prst in kamnine zelo težko izmeriti.

\subsection{Namen in cilj naloge}

Glede na navedena dejstva v Uvodu, sem v prispevku skušala preceniti o kakšnih trendih spreminjanja pretokov lahko govorimo na podlagi podatkov, ki so mi bili na voljo v Agenciji Republike Slovenije za okolje (v nadaljevanju ARSO), ter preko tega o spreminjanju geografskih značilnosti manjših porečij. Razpoložljivi hidrološki podatki naj bi potrdili domnevo o povečevanju hidroloških ekstremov, skladno s poznanimi klimatskimi spremembami v zadnjih desetletjih, ki naj bi vplivale tudi na zmanjševanje vodnik količin porečij.

Problemi, ki so jih klimatske spremembe prinesle, so ena bistvenih vprašanj znanosti in prav vodni viri so najbolj odvisni od teh sprememb. Poznavanje klimatskih pojavov nam $\mathrm{v}$ hidrologiji pomaga predvsem pri določanju hidroloških procesov, tako ekstremov, kot tudi povprečij. Na tem mestu bi 
lahko govorili o povezavi med padavinami in odtokom, kar je hkrati tudi cilj hidrogeografskih analiz, namreč vodna bilanca. Ta je vezana na krogotok vode $\mathrm{v}$ naravi in nam pove, da je količina odtekle, izhlapele in infiltrirane vode na nekem porečju, enaka količini padavin tega porečja.

\subsection{Delovna metoda}

Vodomerne postaje, katerih podatke sem uporabljala za analize, sem izbrala na podlagi treh bistvenih kriterijev:

- podatki o pretokih morajo biti na voljo za 45 letni niz 1955 - 1999

- niz ne sme biti prekinjen

- postaje, oziroma njihova vodozbirna zaledja morajo biti razporejene tako, da pokrivajo celo Slovenijo in da imajo $s$ tem porečja različne rečne režime. V primeru, ko je na eni reki več vodomernih postaj, je razvodnica med porečji določena do mesta vodomerne postaje na reki, trend spreminjanja pretokov pa je odraz lastnosti tudi gorvodno ležečega porečja. Primer je reka Sava, na kateri so štiri vodomerne postaje.

Opozorim naj na določitev razvodnic izbranih porečij. Te so določene na ARSO iz topografskih kart merila 1:25000 na podlagi reliefnih značilnosti, predvsem v severovzhodni Sloveniji so določene s pomočjo podatkov o podtalnici, v Julijskih Alpah pa celo na podlagi sledenj.

Ko imamo zbrane vse podatke o pretokih in že izrisane trendne linije, lahko na podlagi enačbe premice ugotavljamo povezanost med podatki posameznih vodomernih postaj. Za izbranih 53 vodomernih postaj sem določila linearne trendne linije pretokov razpoložljivih opazovanih obdobij, da bi dobili boljšo predstavo o trenutnem stanju, oziroma o tendencah merjenih pretokov. Analiza arhivskih podatkov o pretokih je bila narejena za srednje letne vrednosti Qsr, letne vrednosti nizkih povprečij Qnp in letne vrednosti visokih konic Qvk. S primerjavo razlik pretokov trendne linije v začetku in na koncu obdobja, sem poskušala ugotoviti enotnost oziroma podobnost med vodomernimi postajami, pri čemer pa sem upoštevala tudi ostale hidrološke in geografske značilnosti.

V nadaljevanju sem linearne trende določila še za letne količine 44 izbranih padavinskih postaj in za spreminjanje srednje vodne gladine 24 postaj podzemne vode. Opazovani niz je bil na vseh postajah 45 letni. 


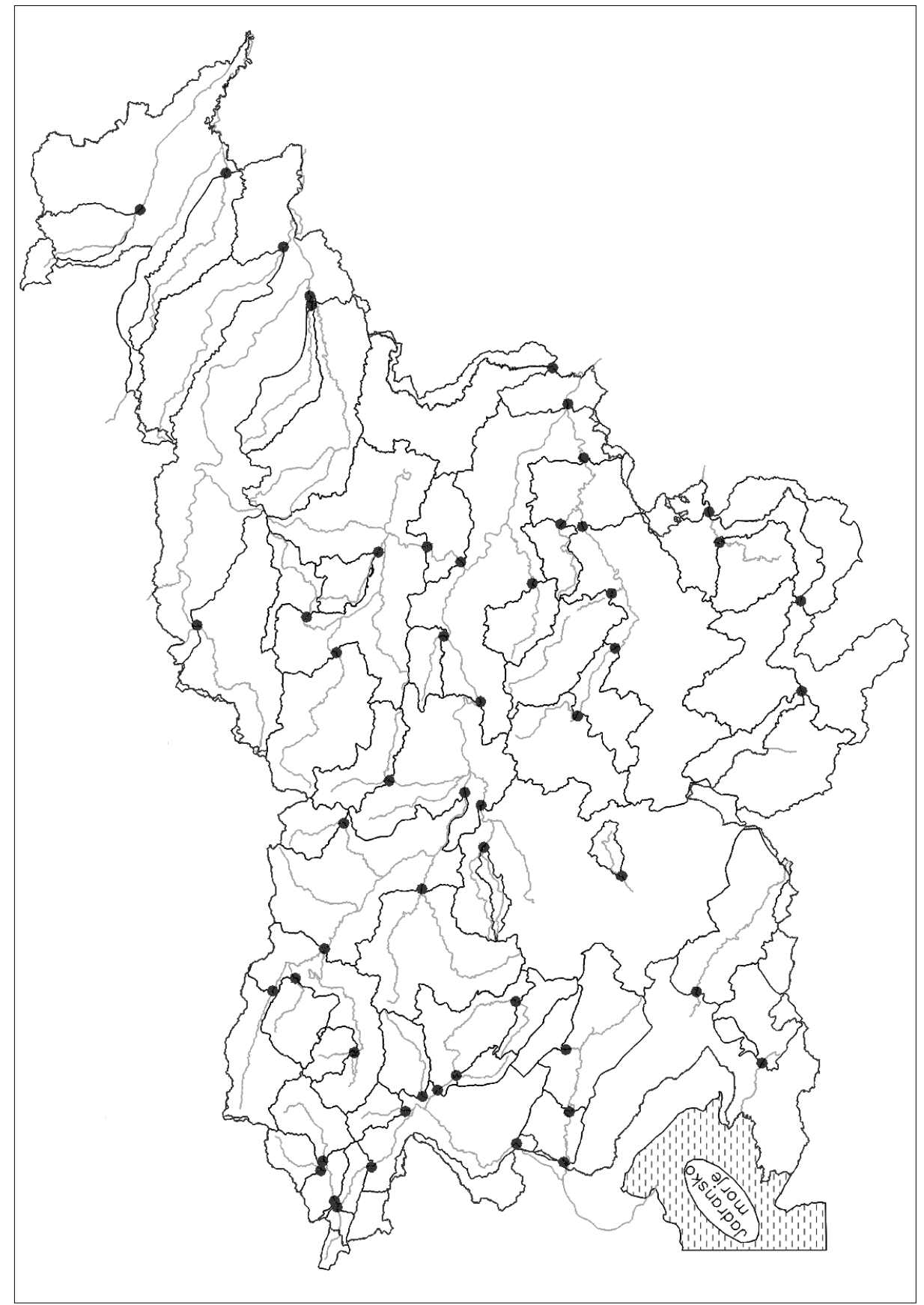

Slika 1: Vodomerne postaje in njihova vodozbirna zaledja 


\section{ANALIZA TRENDOV SPREMINJANJA PRETOKOV}

Trendi spreminjanja pretokov nam kažejo, kakšne so tendence hidroloških stanj v daljšem opazovanem obdobju. Glede na podnebne spremembe predvidevamo, da se spreminjajo predvsem izredna hidrološka stanja, torej da se najvišji in najnižji letni pretok v daljšem obdobju povečuje oziroma zmanjšuje. Ob tem pa nas seveda tudi zanima, ali kaže trend podatkov o srednjem letnem pretoku na izbranem profilu reke naraščanje ali upadanje in kakšne so razlike po Sloveniji.

Ko imamo zbrane vse podatke o pretokih in že izrisane linearne trendne linije, lahko na podlagi razlike pretoka, ki ga izkazuje potek trendne linije $\mathrm{v}$ začetnem in $\mathrm{v}$ končnem obdobju, ugotavljamo povezanost med podatki posameznih vodomernih postaj. V preglednici 1 je razvidno, da se v 45 letnem nizu 1955-1999, predvidevanja o povečevanju ekstremov niso v celoti potrdila.

Od 53-ih vodomernih postaj je na 46-ih vodomernih postajah trend nizkih povprečij pretokov padajoč, kar pomeni, da so v izbranem opazovanem obdobju nizke vode na izbranih profilih vse nižje. To potrjuje tudi dejstvo, da so bili kar na 19 vodomernih postajah zabeleženi obdobni ekstremi v zadnjih osmih letih obdobja (na osmih postajah leta 1993), v letu 1989 pa še v 4-ih primerih. S tem se odstopanje od srednje obdobne vrednosti povečuje, kar nakazuje padajoči trend. Opozorim naj še, da je trend upadanja nizkih povprečij pretokov zelo blag in na 19-ih vodomernih postajah predstavlja le nekaj procentov zmanjšanja, tolikšna pa je lahko tudi napaka meritev. Za postaje Stara Fužina, Suha, Zagorje, Martinja vas, Rakovec, Gradac, Cerknica, Šoštanj, Levec, Podbukovje, Škocjan, Žaga, Dolenja Trebuša, Dornberk in Miren bi lahko govorili o nespremenjenem trendu nizkih povprečij pretokov. Pri tem je zanimivo, da so naštete vodomerne postaje $\mathrm{v}$ različnih pokrajinah ter imajo tudi različne rečne režime.

Rahlo naraščajoč trend nizkih konic imajo postaje Prečna, Tržec, Zamušani in obe postaji Pomurja: Pristava in Polana. Med izbranimi vodomernimi postajami sta izjemi le Videm in Cerkvenikov mlin, ki imata trend nizkih pretokov naraščajoč.

Trendi visokih konic letnih pretokov prav tako kažejo upadanje oziroma zmanjševanje ekstremov na 25 -ih vodomernih postajah. Na postajah Čatež na Savi, Log Čezsoški na Soči in Petrina ter Radenci na Kolpi je trend visokih konic nekoliko bolj padajoč, na ostalih postajah pa se visoke konice le malo zmanjšujejo. Očitno naraščajoč trend sem zabeležila na rekah Dravinja, Savinja, Sava, Sotla, Kolpa, Krka in Soča. Tu so bili obdobni ekstremi zabeleženi $v$ zadnjih desetih letih opazovanega obdobja. Vodozbirno zaledje vodomernih postaj z vedno večjo ogroženostjo pred poplavami, pokriva $26 \%$ obravnavanega površja, oziroma 21 \% površja Slovenije. 
Preglednica 1: Naklon trendne linije pretokov površinskih voda in razlika količine vode v profilu

\begin{tabular}{|c|c|c|c|c|c|c|c|c|}
\hline $\begin{array}{l}\text { Vodomerna } \\
\text { postaja }\end{array}$ & Reka & Qnp & Qvk & Qsr & $\begin{array}{c}\text { Qsr1 } \\
\left(\mathrm{m}^{3} / \mathrm{s}\right)\end{array}$ & $\begin{array}{c}\text { Qsr2 } \\
\left(\mathrm{m}^{3} / \mathrm{s}\right)\end{array}$ & $\begin{array}{c}\text { razlika } \\
\left(\mathrm{m}^{3} / \mathrm{s}\right)\end{array}$ & $\begin{array}{c}\% \\
\text { razlike }\end{array}$ \\
\hline Pristava & Ščavnica & 0,00 & 0,42 & $-0,01$ & 2,65 & 2,2 & 0,45 & 17,0 \\
\hline Polana & Ledava & 0,00 & $-0,06$ & $-0,01$ & 1,5 & 1,1 & 0,4 & 26,7 \\
\hline Otiški Vrh & Meža & $-0,01$ & $-0,54$ & $-0,06$ & 14 & 11,5 & 2,5 & 17,9 \\
\hline Videm & Dravinja & 0,01 & 1,46 & $-0,03$ & 12,5 & 11 & 1,5 & 12 \\
\hline Tržec & Polskava & 0,00 & 0,62 & 0,02 & 2,1 & 3 & 0,9 & 42,9 \\
\hline Zamušani & Pesnica & 0,00 & 0,53 & $-0,03$ & 6 & 4,8 & 1,2 & 20 \\
\hline Jesenice & Sava Dolin. & $-0,01$ & $-0,20$ & $-0,08$ & 12,5 & 9 & 3,5 & 28 \\
\hline Podhom & Radovna & $-0,02$ & $-0,26$ & $-0,05$ & 9 & 7 & 2 & 22,2 \\
\hline Stara Fužina & Mostnica & 0,00 & $-0,28$ & $-0,02$ & 3,8 & 2,9 & 0,9 & 23,7 \\
\hline Radovljica & Sava & $-0,05$ & $-0,10$ & $-0,21$ & 49,5 & 40 & 9,5 & 19,2 \\
\hline Śentjakob & Sava & $-0,18$ & 0,39 & $-0,66$ & 104 & 76 & 28 & 26,9 \\
\hline Litija & Sava & $-0,14$ & 1,73 & $-1,06$ & 191 & 144 & 47 & 24,6 \\
\hline Čatež & Sava & $-0,41$ & $-2,56$ & $-1,60$ & 320 & 252 & 68 & 21,3 \\
\hline Kokra & Kokra & $-0,01$ & 0,02 & $-0,03$ & 5 & 3,8 & 1,2 & 24 \\
\hline Suha & Sora & 0,00 & 0,87 & $-0,10$ & 22,5 & 18 & 4,5 & 20 \\
\hline Kamnik & Kamniška B. & $-0,02$ & $-0,27$ & $-0,03$ & 8,2 & 6,8 & 1,4 & 17,1 \\
\hline Zagorje & Medija & 0,00 & 0,88 & $-0,01$ & 2,4 & 2,1 & 0,3 & 12,5 \\
\hline Martinja vas & Mirna & 0,00 & 0,15 & $-0,01$ & 2,8 & 2,6 & 0,2 & 7,1 \\
\hline Rakovec & Sotla & 0,00 & 2,26 & 0,03 & 8,5 & 10 & 1,5 & 17,6 \\
\hline Petrina & Kolpa & $-0,03$ & $-3,17$ & $-0,07$ & 28 & 25 & 3 & 10,7 \\
\hline Radenci & Kolpa & $-0,06$ & $-1,53$ & $-0,25$ & 59 & 48 & 11 & 18,6 \\
\hline Metlika & Kolpa & $-0,05$ & 2,83 & $-0,22$ & 78,5 & 69 & 9,5 & 12,1 \\
\hline Gradac & Lahinja & 0,00 & $-0,02$ & $-0,03$ & 6,5 & 5 & 1,5 & 23,1 \\
\hline Moste & Ljubljanica & $-0,05$ & $-0,35$ & $-0,15$ & 61 & 54 & 7 & 11,5 \\
\hline Razori & Šujica & $-0,01$ & 0,03 & $-0,01$ & 1,8 & 1,2 & 0,6 & 33,3 \\
\hline Cerknica & Cerkniščica & 0,00 & $-0,20$ & $-0,01$ & 1,3 & 0,9 & 0,4 & 30,8 \\
\hline Nazarje & Savinja & $-0,02$ & 1,98 & $-0,05$ & 18 & 15,7 & 2,3 & 12,8 \\
\hline Laško & Savinja & $-0,03$ & 4,12 & $-0,06$ & 42,5 & 40 & 2,5 & 5,9 \\
\hline Veliko Širje & Savinja & $-0,03$ & 8,21 & $-0,04$ & 46 & 44 & 2 & 4,3 \\
\hline Šoštanj & Paka & 0,00 & $-0,01$ & $-0,01$ & 2,6 & 2,2 & 0,4 & 15,4 \\
\hline Levec & Ložnica & 0,00 & 0,56 & $-0,01$ & 2 & 1,5 & 0,5 & 25 \\
\hline Podbukovje & Krka & $-0,01$ & 0,01 & $-0,06$ & 9,5 & 7 & 2,5 & 26,3 \\
\hline Dvor & Krka & $-0,01$ & 2,01 & $-0,06$ & 18,5 & 16 & 2,5 & 13,5 \\
\hline Gorenja Gomila & Krka & 0,00 & 0,16 & $-0,27$ & 50 & 40 & 10 & 20,0 \\
\hline Podbočje & Krka & $-0,01$ & $-0,72$ & $-0,25$ & 60 & 49 & 11 & 18,3 \\
\hline Prečna & Prečna & 0,00 & 0,01 & $-0,01$ & 4,8 & 4,2 & 0,6 & 12,5 \\
\hline
\end{tabular}


Trendi spreminjanja pretokov slovenskih rek

\begin{tabular}{|l|l|r|r|r|r|r|r|r|}
\hline \multirow{2}{*}{ Škocjan } & Radulja & 0,00 & 0,35 & 0,00 & 1,9 & 1,8 & 0,1 & 5,3 \\
\hline \multirow{2}{*}{ Kršovec } & Soča & $-0,02$ & 0,31 & $-0,05$ & 13 & 10,7 & 2,3 & 17,7 \\
\hline \multirow{2}{*}{ Kog Čezsoški } & Soča & $-0,02$ & $-1,23$ & $-0,16$ & 28,5 & 21,5 & 7 & 24,6 \\
\cline { 2 - 9 } Solkan & Soča & $-0,02$ & 2,55 & $-0,13$ & 37 & 31 & 6 & 16,2 \\
\hline \multirow{2}{*}{ Kal } & Soča & $-0,11$ & 7,21 & $-0,42$ & 103 & 85 & 18 & 17,5 \\
\hline \multirow{2}{*}{ Žaga } & Koritnica & $-0,01$ & $-0,38$ & $-0,04$ & 8,2 & 6,5 & 1,7 & 20,7 \\
\hline Tolmin & Učja & 0,00 & $-0,19$ & $-0,01$ & 3,7 & 3,2 & 0,5 & 13,5 \\
\hline Podroteja & Tolminka & $-0,01$ & 0,31 & $-0,01$ & 8 & 7,7 & 0,3 & 3,8 \\
\hline Hotešk & Idrijca & $-0,01$ & 0,05 & $-0,08$ & 11 & 7,4 & 3,6 & 32,7 \\
\hline Dol. Trebuša & Idrijca & $-0,02$ & $-0,03$ & $-0,08$ & 26 & 22,5 & 3,5 & 13,5 \\
\hline Bača pri Modr. & Trebuša & 0,00 & $-0,45$ & $-0,01$ & 3 & 2,8 & 0,2 & 6,7 \\
\hline Dornberk & $-0,01$ & 0,92 & $-0,03$ & 7,7 & 6,4 & 1,3 & 16,9 \\
\hline Miren & Vipava & 0,00 & $-0,58$ & $-0,09$ & 16,6 & 13 & 3,6 & 21,7 \\
\hline \multirow{2}{*}{ Ajdov̌̌čina } & Vipava & 0,00 & $-0,23$ & $-0,04$ & 18,5 & 16,5 & 2 & 10,8 \\
\hline Cerkvenik. mlin & Hubelj & $-0,01$ & 0,11 & $-0,01$ & 3,1 & 2,7 & 0,4 & 12,9 \\
\hline Kubed & Reka & 0,01 & $-0,21$ & $-0,05$ & 9,3 & 7,3 & 2 & 21,5 \\
\hline & Rižana & $-0,01$ & $-0,59$ & $-0,04$ & 5 & 3,2 & 1,8 & 36 \\
\hline
\end{tabular}

Tudi trend srednjih pretokov je na vseh vodomernih postajah padajoč. Izjemi sta le vodomerni postaji Tržec na Polskavi in Rakovec na Sotli, ki imata naraščajoč trend tudi pri visokih konicah in skoraj nespremenjen trend nizkih povprečij. Splošno upadanje srednjih pretokov na rekah cele Slovenije je vredno večje pozornosti. Ali je to pokazatelj splošnega upadanja količine vode, ki teče po naših rekah, ter je lahko ugotovljeno stanje rahlo zaskrbljujoče z vidika vodnega gospodarstva in vodnih zalog? Ali se na ta način tudi odražajo klimatske spremembe in splošno segrevanje ozračja? Ali je to odraz spreminjanja rabe tal in širjenja gozdnih površin? In nenazadnje, kaj dosedanji trend splošnega zniževanja srednjih letnih vrednosti pretokov pomeni z vidika vodne bilance? Kljub dejstvom, pa na podlagi 45 letnega niza le ne moremo prehitevati z zaključki. Ob pregledovanju arhivskih dokumentov in hidroloških podatkov, se je izkazalo obdobje kratko za konkretna sklepanja. Iz podatkov, ki so na voljo na ARSO, sem izračunala trende še za 67 letne nize, za 4 vodomerne postaje. Rezultati so prikazani v preglednici 2.

Iz primerjave obeh nizov je razvidno manjše neujemanje trendov. Nizki pretoki kažejo padajoč trend na vodomernih postajah Radovne, Save in Savinje, ki imajo hudourniški značaj, v obeh primerih, medtem ko je za daljše obdobje trend nizkih pretokov Krke, ki je kraška reka, naraščajoč. Trend visokih konic je v daljšem obdobju opazovanj na vseh postajah vse bolj izrazit. Srednji letni pretoki imajo, tako v daljšem, kot v krajšem opazovanem obdobju na vseh vodomernih postajah, padajoč trend. 
Preglednica 2: Trendi pretokov za obdobje 1933 - 1999

\begin{tabular}{|c|c|c|c|c|c|c|c|c|}
\hline $\begin{array}{l}\text { Vodomerna } \\
\text { postaja }\end{array}$ & Reka & Qnp & Qvk & Qsr & $\begin{array}{c}\text { Qsr1 } \\
\left(\mathbf{m}^{3} / \mathbf{s}\right)\end{array}$ & $\begin{array}{c}\text { Qsr2 } \\
\left(\mathrm{m}^{3} / \mathrm{s}\right)\end{array}$ & $\begin{array}{c}\text { razlika } \\
\left(\mathrm{m}^{3} / \mathrm{s}\right)\end{array}$ & $\begin{array}{c}\% \\
\text { razlike }\end{array}$ \\
\hline Podhom & Radovna & $-0,01$ & $-0,48$ & $-0,04$ & 9,6 & 7,1 & 2,5 & 26 \\
\hline Litija & Sava & $-0,03$ & 0,96 & $-0,53$ & 187 & 152 & 35 & 18,7 \\
\hline Nazarje & Savinja & $-0,01$ & 1,5 & $-0,05$ & 19 & 15,5 & 3,5 & 18,4 \\
\hline Podbočje & Krka & 0,04 & $-0,46$ & $-0,15$ & 60 & 51 & 9 & 15 \\
\hline
\end{tabular}

Povprečno upadanje srednjih letnih pretokov na analiziranih vodomernih postajah, katerih vodozbirno zaledje pokriva $17910,5 \mathrm{~km}^{2}$, je v obravnavanem obdobju doseglo kar 18,2 \%. Približno povprečen upad je zaznati na 14 vodomernih postajah. Nadpovprečen upad ima kar 20 vodomernih postaj, med njimi tudi vse postaje na reki Savi, podpovprečno upadanje pa je najbolj izrazito na Kolpi in Savinji.

\section{RAZVRŠČANJE VODOMERNIH POSTAJ GLEDE NA TREND SPREMINJANJA PRETOKOV}

Pričakovane spremembe količin vode $\mathrm{v}$ strugi so se $\mathrm{v}$ obravnavanem obdobju potrdile le v primeru 17-ih vodomernih postaj katerih vodozbirno zaledje pokriva $5300 \mathrm{~km}^{2}$ ali $29,6 \%$ obravnavane površine. Postaje so na rekah Sava, Kokra, Kolpa, Šujica, Savinja, Krka, Soča, Tolminka, Idrijca, Bača in Hubelj. $\mathrm{V}$ vseh primerih gre za opazno zmanjševanje pretoka nizkih povprečij in za naraščanje trenda visokih konic. Trend srednjih letnih pretokov se zmanjšuje od 4,3\% $\left(2 \mathrm{~m}^{3} / \mathrm{s}\right)$ v Velikem Širju na Savinji, vse do $33,3 \%\left(0,6 \mathrm{~m}^{3} / \mathrm{s}\right)$ na postaji Razori na Šujici. Na še 11 vodomernih postajah bi lahko govorili o nekoliko manj tipičnem spreminjanju vodnih količin v strugi, saj ostaja trend nizkih povprečij pretokov praktično nespremenjen. Vodozbirna zaledja teh postaj pokrivajo $3858 \mathrm{~km}^{2}$ ali $21,5 \%$ obravnavane površine. Med temi postajami sta tudi obe postaji z naraščajočim trendom srednjih pretokov. Nepričakovano spreminjanje trendov pretokov se je pokazalo v primeru 23 -ih vodomernih postaj. Trend nizkih pretokov je ostal nespremenjen ali je padajoč, prav tako pa je padajoč tudi trend visokih konic pretokov. Postaje so razporejene po celi Sloveniji, njihovo vodozbirno zaledje pa pokriva $7755 \mathrm{~km}^{2}$ ali dobrih $43 \%$ obravnavane površine. Vodomerni postaji Cerkvenikov mlin na Reki in Videm na Dravinji sta izjemi, saj je tu trend spreminjanja nizkih pretokov naraščajoč. Vodozbirno zaledje teh dveh postaj predstavlja 5,6 \% obravnavane površine. $\mathrm{V}$ preglednici 3 so razvrščene postaje glede na trende spreminjanja pretokov. 
Trendi spreminjanja pretokov slovenskih rek

Preglednica 3: Razvrščanje postaj glede na trende spreminjanja pretokov

\begin{tabular}{|c|c|c|c|c|c|}
\hline $\begin{array}{l}\text { Vodomerna } \\
\text { postaja }\end{array}$ & Reka & Skupina & $\begin{array}{l}\text { Vodomerna } \\
\text { postaja }\end{array}$ & Reka & Skupina \\
\hline Pristava & Ščavnica & $\mathrm{A}$ & Laško & Savinja & $\mathrm{A}$ \\
\hline Polana & Ledava & $\mathrm{B}$ & Veliko Širje & Savinja & A \\
\hline Otiški Vrh & Meža & $\mathrm{B}$ & Šoštanj & Paka & $\mathrm{B}$ \\
\hline Videm & Dravinja & $\mathrm{C}$ & Levec & Ložnica & A \\
\hline Tržec & Polskava & $\mathrm{C}$ & Podbukovje & Krka & A \\
\hline Zamušani & Pesnica & A & Dvor & Krka & A \\
\hline Jesenice & Sava Dolinka & $\mathrm{B}$ & Gorenja Gomila & Krka & A \\
\hline Podhom & Radovna & $\mathrm{B}$ & Podbočje & Krka & $\mathrm{B}$ \\
\hline Stara Fužina & Mostnica & $\mathrm{B}$ & Prečna & Prečna & A \\
\hline Radovljica & Sava & $\mathrm{B}$ & Škocjan * & Radulja & A \\
\hline Šentjakob & Sava & A & Kršovec & Soča & A \\
\hline Litija & Sava & A & Log Čezsoški & Soča & $\mathrm{B}$ \\
\hline Čatež & Sava & B & Kobarid & Soča & A \\
\hline Kokra & Kokra & A & Solkan & Soča & A \\
\hline Suha & Sora & $\mathrm{A}$ & Kal & Koritnica & $\mathrm{B}$ \\
\hline Kamnik & Kamniška B. & $\mathrm{B}$ & $\check{Z} a g a$ & Učja & $\mathrm{B}$ \\
\hline Zagorje & Medija & A & Tolmin & Tolminka & A \\
\hline Martinja Vas & Mirna & A & Podroteja & Idrijca & A \\
\hline Rakovec & Sotla & $\mathrm{C}$ & Hotešk & Idrijca & $\mathrm{B}$ \\
\hline Petrina & Kolpa & $\mathrm{B}$ & Dolenja Trebuša & Trebuša & $\mathrm{B}$ \\
\hline Radenci & Kolpa & $\mathrm{B}$ & Bača Pri Modr. & Bača & A \\
\hline Metlika & Kolpa & $\mathrm{A}$ & Dornberk & Vipava & $\mathrm{B}$ \\
\hline Gradac & Lahinja & $\mathrm{B}$ & Miren & Vipava & $\mathrm{B}$ \\
\hline Moste & Ljubljanica & $\mathrm{B}$ & Ajdovščina & Hubelj & $\mathrm{A}$ \\
\hline Razori & Šujica & A & Cerkvenik. mlin & Reka & $\mathrm{C}$ \\
\hline Cerknica & Cerkniščcica & $\mathrm{B}$ & Kubed & Rižana & $\mathrm{B}$ \\
\hline Nazarje & Savinja & A & & & \\
\hline
\end{tabular}

$\begin{array}{cccc} & \text { Qnp } & \text { Qvk } & \text { Qsr } \\ A & \text { upada } & \text { narašča } & \text { upada } \\ B & \text { upada } & \text { upada } & \text { upada } \\ \text { C } & \text { upada } & \text { narašča } & \text { narašča } \\ & \text { narašča } & \text { upada } & \text { upada } \\ & \text { narašča } & \text { upada } & \text { narašca }\end{array}$




\section{TRENDI SPREMINJANJA LETNIH KOLIČIN PADAVIN IN GLADIN PODZEMNIH VODA}

Podatke o letni količini padavin na 44 merilnih postajah sem dobila na ARSO. Postaje so po Sloveniji precej enakomerno razporejene, bistvenega pomena za izbor postaj pa je bil ustrezen 45 letni niz podatkov. Med vsemi postajami je na 11 merilnih mestih trend spreminjanja letne količine padavin naraščajoč. Delež razlike količine padavin, ki jo izraža začetek oziroma konec trendne linije, je največji na postaji Kobilje (14,9 \%), najmanjši pa na postajah Kadrenci in Cankova (le 0,2 \%). Razen postaj Ambrož pod Krvavcem, Moravče in Dvor, so vse postaje $\mathrm{z}$ naraščajočim trendom padavin $\mathrm{v}$ vzhodni ali severovzhodni Sloveniji. Povprečno naraščanje količine padavin vseh postaj je le 4,2 \%. Na ostalih 33 postajah je trend padajoč. Povprečje upadanja padavin vseh postaj je 11,2 \%. Podpovprečno upadanje ali do $8 \%$ upada ima 9 postaj, nadpovprečno upadanje ali nad $13 \%$ pa 10 postaj. Iz pregleda vseh postaj lahko ugotovimo, da je za zahodno in južno Slovenijo značilno upadanje padavin, za osrednjo in severovzhodno pa naraščanje. Podatki so navedeni v preglednici 4.

Preglednica 4: Naklon trendne linije padavin in razlika $v$ količini

\begin{tabular}{|l|r|r|r|r|r|r|}
\hline Ime postaje & m.nm.v. & $\begin{array}{c}\text { TREND } \\
\mathbf{1 9 5 5 - 1 9 9 9}\end{array}$ & $\begin{array}{c}\text { pad1 } \\
\text { (mm) }\end{array}$ & $\begin{array}{c}\text { pad2 } \\
\text { (mm) }\end{array}$ & $\begin{array}{c}\text { razlika } \\
\text { (mm) }\end{array}$ & $\begin{array}{r}\text { \% } \\
\text { razlike }\end{array}$ \\
\hline Log pod Mangartom & 650 & $-78,1$ & 2560 & 2255 & 305 & 11,9 \\
\hline Livek & 695 & $-131,4$ & 2760 & 2185 & 575 & 20,8 \\
\hline Šempas & 104 & $-68,4$ & 1600 & 1300 & 300 & 18,8 \\
\hline Kal nad Kanalom & 688 & $-64,5$ & 2585 & 2300 & 285 & 11,0 \\
\hline Mrzla Rupa & 930 & $-54,2$ & 2825 & 2590 & 235 & 8,3 \\
\hline Movraž & 226 & $-6,2$ & 1282 & 1255 & 27 & 2,1 \\
\hline Bohinjska Bistrica & 507 & $-38,4$ & 2227 & 2058 & 169 & 7,6 \\
\hline Vipava & 104 & $-38,2$ & 1710 & 1540 & 170 & 9,9 \\
\hline Razdrto & 577 & $-122,0$ & 1950 & 1410 & 540 & 27,7 \\
\hline Javorniški Rovt & 940 & $-80,1$ & 2145 & 1795 & 350 & 16,3 \\
\hline Podgrad pri Il. Bistrici & 560 & $-59,7$ & 1713 & 1450 & 263 & 15,4 \\
\hline Železniki & 458 & $-54,0$ & 1980 & 1745 & 235 & 11,9 \\
\hline Lučine & 639 & $-51,9$ & 1935 & 1705 & 230 & 11,9 \\
\hline Škofja Loka (Binkelj) & 340 & $-24,5$ & 1680 & 1590 & 90 & 5,4 \\
\hline Zgornje Bitnje & 378 & $-32,6$ & 1530 & 1405 & 125 & 8,2 \\
\hline Cerknica & 576 & $-25,0$ & 1755 & 1645 & 110 & 6,3 \\
\hline
\end{tabular}


Trendi spreminjanja pretokov slovenskih rek

\begin{tabular}{|c|c|c|c|c|c|c|}
\hline Tomišelj & 299 & $-20,2$ & 1550 & 1460 & 90 & 5,8 \\
\hline Ambrož pod Krvavcem & 990 & 14,3 & 1544 & 1610 & 66 & 4,1 \\
\hline Solčava & 658 & $-55,5$ & 1685 & 1440 & 245 & 14,5 \\
\hline Luče & 520 & $-43,6$ & 1715 & 1583 & 132 & 7,7 \\
\hline Moravče & 381 & 13,6 & 1220 & 1280 & 60 & 4,9 \\
\hline Grčarice & 520 & $-38,5$ & 1650 & 1480 & 170 & 10,3 \\
\hline Dvor & 203 & 6,3 & 1185 & 1213 & 28 & 2,4 \\
\hline Kotlje & 450 & $-22,7$ & 1225 & 1125 & 100 & 8,2 \\
\hline Zgornji Razbor & 864 & $-7,0$ & 1265 & 1234 & 31 & 2,5 \\
\hline Gomilsko & 294 & 14,4 & 1280 & 1340 & 60 & 4,7 \\
\hline Kočevske Poljane & 200 & $-33,2$ & 1470 & 1325 & 145 & 9,9 \\
\hline Predgrad & 375 & $-69,5$ & 1575 & 1270 & 305 & 19,4 \\
\hline Mislinja & 589 & 17,9 & 1186 & 1264 & 78 & 6,6 \\
\hline Laško & 223 & $-3,2$ & 1199 & 1185 & 14 & 1,2 \\
\hline Cerovec & 190 & $-47,2$ & 1298 & 1090 & 208 & 16,0 \\
\hline Ribnica Na Pohorju & 680 & $-39,9$ & 1385 & 1210 & 175 & 12,6 \\
\hline Vitanje & 478 & $-26,7$ & 1188 & 1070 & 118 & 9,9 \\
\hline Vojnik & 273 & 1,8 & 1109 & 1117 & 8 & 0,7 \\
\hline Gorenjci (Adlešiči) & 250 & $-24,2$ & 1305 & 1200 & 105 & 8,0 \\
\hline Ložice & 560 & 6,0 & 1230 & 1255 & 25 & 2,0 \\
\hline Kostanjevica & 158 & $-21,9$ & 1205 & 1108 & 97 & 8,0 \\
\hline Senovica & 290 & $-48,7$ & 1150 & 935 & 215 & 18,7 \\
\hline Podsreda & 300 & $-7,8$ & 1158 & 1125 & 33 & 2,8 \\
\hline Ptuj & 235 & 25,1 & 965 & 1017 & 52 & 5,4 \\
\hline Kadrenci & 316 & 0,4 & 940,8 & 942,5 & 1,7 & 0,2 \\
\hline Cankova & 214 & 0,3 & 823,5 & 824,8 & 1,3 & 0,2 \\
\hline Srednja Bistrica & 170 & $-43,0$ & 910 & 720 & 190 & 20,9 \\
\hline Kobilje & 190 & 24,9 & 740 & 850 & 110 & 14,9 \\
\hline
\end{tabular}

Podatke o srednjih letnih gladinah postaj podzemnih voda sem prav tako dobila na ARSO za obdobje 45 let. Trend spreminjanja vodnih količin 24-ih postaj na 12 aluvialnih vodonosnikih je, razen štirih vodonosnikov, prav tako padajoč. Vodna gladina se je najbolj znižala na postajah Plitvice na Apaškem polju, Dornava na Ptujskem polju in v Šempetru v Vipavsko-Soški dolini. V vseh primerih je presegla $120 \mathrm{~cm}$ znižanja v obravnavanem obdobju, kar v primeru polj vzhodne Slovenije pomeni dobrih $12 \%$ glede na domnevno globino vodonosnika, v Posočju pa $5 \%$. Srednja vrednost upadanja gladin vseh 
polj je 6,6 \%. Takšno upadanje je opazno na postaji Miren. Nekoliko nadpovprečen upad pa je, poleg že omenjenih postaj, opaziti še na Brežiškem in Šentjernejskem polju (6\%). Nespremenjen trend nihanja gladin podtalnice ima Kamniško Bistriška ravan, rahlo naraščajoč trend pa je opaziti na postaji Rankovci na Prekmurskem polju, v Krški vasi na Krškem polju in na dveh postajah Spodnje Savinjske doline. Spreminjanje gladin podzemne vode je razvidno v preglednici 5 .

Preglednica 5: Spreminjanje gladin podzemne vode na aluvialnih vodonosnikih

\begin{tabular}{|c|c|c|c|c|}
\hline Polje & Postaja & H1 (m.n.m.) & H2 (m.n.m.) & razlika $(\mathrm{cm})$ \\
\hline \multirow[t]{3}{*}{ Prekmursko } & Rankovci & 196 & 196,7 & 70 \\
\hline & Lipovci & 177,98 & 177,64 & -34 \\
\hline & Renkovci & 172,9 & 172,4 & -50 \\
\hline \multirow[t]{4}{*}{ Mursko } & Bunčani & 183,9 & 183,77 & -13 \\
\hline & Ključarovci & 179,75 & 178,9 & -85 \\
\hline & Zg.Kraplje & 175,87 & 175,81 & -6 \\
\hline & Veščica & 170,37 & 170,09 & -28 \\
\hline Apaško & Plitvice & 216 & 214,7 & -130 \\
\hline Ptujsko & Dornava & 215,3 & 214,1 & -120 \\
\hline \multirow[t]{2}{*}{ Dravsko } & Zg.Jablane & 241,5 & 240,3 & -120 \\
\hline & Sp.Hajdina & 221,4 & 220,68 & -72 \\
\hline \multirow[t]{3}{*}{ Sp.Savinjska } & Breg & 280,77 & 280,835 & 6,5 \\
\hline & Zg. Grušovlje & 278,96 & 279,15 & 19 \\
\hline & Gotovlje & 260,1 & 259,8 & -30 \\
\hline \multirow[t]{2}{*}{ Bolska } & Parižlja & 286,84 & 286,87 & 3 \\
\hline & Dolenja Vas & 271,34 & 271,32 & -2 \\
\hline Brežiško & Bukošek & 149,6 & 149 & -60 \\
\hline Krško & Krška Vas & 141,25 & 141,75 & 50 \\
\hline \multirow[t]{2}{*}{ Šentjernejsko } & Drama & 153,3 & 153 & -30 \\
\hline & Šentjakob & 152,35 & 151,45 & -90 \\
\hline Kamniška Bistrica & Podgorje & 344,23 & 344,27 & 4 \\
\hline \multirow[t]{3}{*}{ Vipavsko-Soška } & Ajdovščina & 101,4 & 100,85 & -55 \\
\hline & Šempeter & 50 & 48,65 & -135 \\
\hline & Miren & 33 & 32,75 & -25 \\
\hline
\end{tabular}




\section{ANALIZA POREČIJ GLEDE NA TRENDE SPREMINJANJA VODNIH KOLIČIN}

\subsection{Pomurje}

Reki Pomurja se po hidrografskih značilnostih razlikujeta. Ledava ima izreden upad trenda Qsr, nespremenjen Qnp, upadajo pa tudi Qvk. Trend spreminjanja gladine podzemnih voda je tudi padajoč, padavine na postajah Kadrenci, Cankova in Kobilje pa imajo naraščajoč trend. Količina vode $\mathrm{v}$ reki se torej $\mathrm{v}$ Prekmurju zmanjšuje, kljub vse večjim letnim količinam padavin. Delno bi to lahko pripisali veliki evapotranspiraciji, delno pa obsežnemu območju melioracij in intenzivni kmetijski rabi območja. Je potemtakem za zmanjševanje količine vode v strugi kriv človek s prekomernim izkoriščanjem pokrajine?

Ščavnica, levi pritok Mure, izkazuje povprečen upad trenda Qsr, nespremenjen Qnp in naraščajoč Qvk. Padavine imajo naraščajoč trend, trend spreminjanja gladine podzemnih voda pa je pod povprečno padajoč. Spreminjanje vodnih količin v porečju Ščavnice torej ni zaskrbljujoče, zmanjševanje vode v strugi pa lahko prav tako povežemo $\mathrm{z}$ evapotranspiracijo, intenzivnim kmetijstvom in melioracijami.

\subsection{Podravje}

Trendi spreminjanja vodnih količin so v Podravju od vseh opisanih 9-ih porečij najbolj raznoliki. Reka Meža ima sicer povprečen upad trenda Qsr in Qnp, vendar pa ima tudi padajoč trend Qvk. Upada tudi količina padavin, v povirnem delu Meže celo nadpovprečno. Za porečje Meže lahko torej ugotovimo, da gre za dejansko upadanje količin vode.

Reki Dravinja, Polskava in Pesnica imajo trend Qnp nespremenjen ali blago naraščajoč, narašča pa tudi trend Qvk. Količine padavin imajo na vseh postajah tega območja naraščajoč trend, gladina podzemne vode pa na Dravskem in Ptujskem polju nadpovprečno upada. Trend Qsr je padajoč, razen na vodomerni postaji Tržec na Polskavi, kjer je opaziti izreden porast, kar 43 \% (iz $2,1 \mathrm{~m}^{3} / \mathrm{s}$ v začetnem obdobju, na $3 \mathrm{~m}^{3} / \mathrm{s}$ na koncu).

Upadanje količine vode $\mathrm{v}$ Podravju glede na ugotovljene trende niti ne predstavlja večjega problema. Nadpovprečno upadanje gladin podzemnih voda lahko pripišemo intenzivni kmetijski rabi, zmernemu upadu Qsr celotnega Podravja pa povprečnemu upadu padavin v povirnem delu vodotokov. 


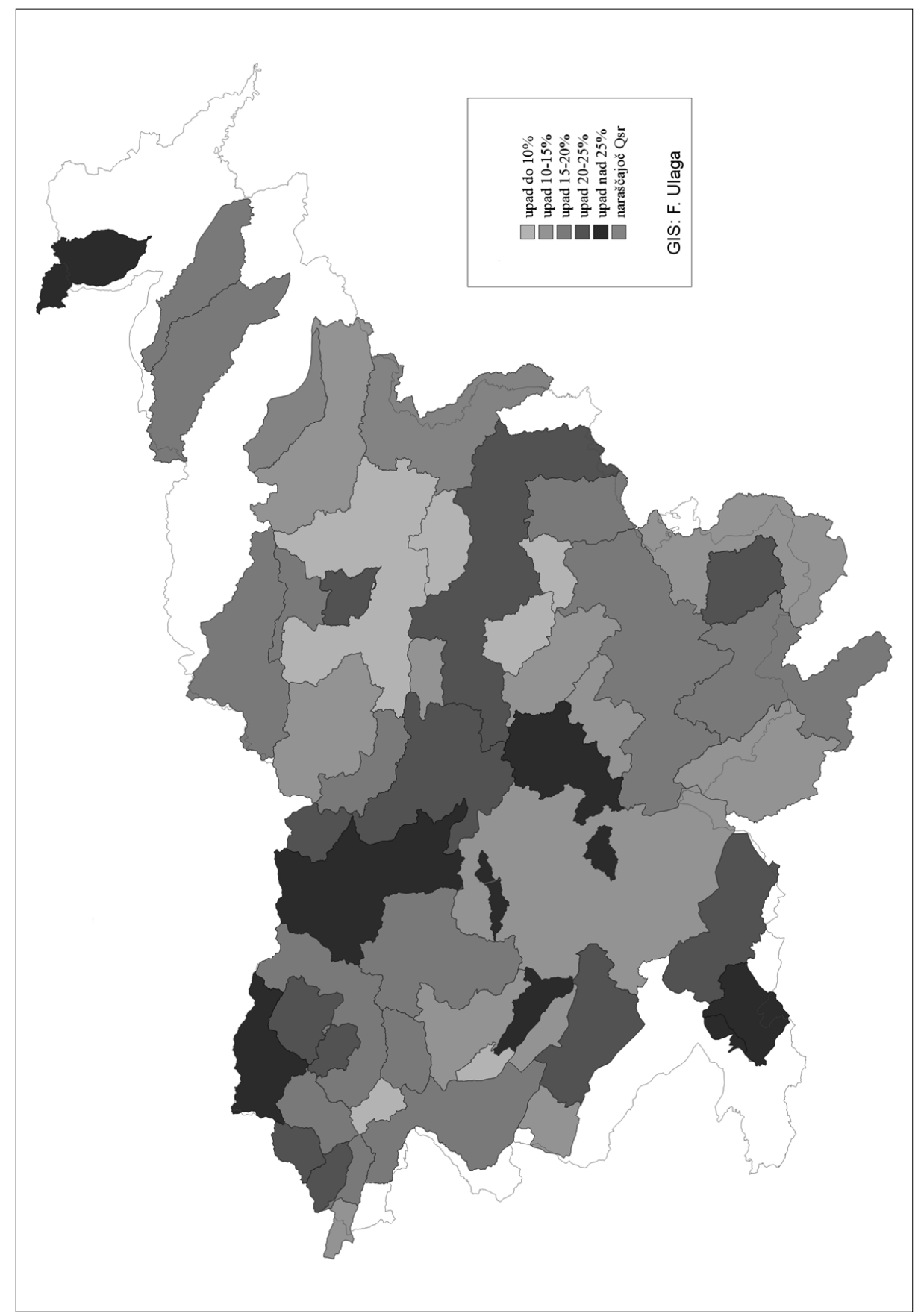

Slika 2: Spreminjanje trenda Qsr 


\subsection{Posavje}

V zgornjem toku Save je trend spreminjanja Qsr nadpovprečno padajoč, upadanje pa je opazno tudi pri Qnp in Qvk. Količina padavin ima tudi padajoč trend, $\mathrm{v}$ hribovitem svetu je upadanje povprečno, na postajah na pobočju gora pa celo nadpovprečno. Pritoka Save Sora in Kamniška Bistrica imata manjše upadanje trenda Qsr in Qvp, Kokra pa tudi sodi med reke s hudourniškim rečnim režimom, z nadpovprečnim trendom upadanja Qsr, zmernim upadom Qnp in porastom Qvk. Padavinska postaja Ambrož pod Krvavcem ima v obravnavanem obdobju celo naraščajoč trend letne količine padavin, blago naraščajoč trend pa ima tudi gladina podtalnice aluvialnega vodonosnika Kamniške Bistrice.

Na ostalih vodomernih postajah Save je trend Qsr prav tako nadpovprečno padajoč, trend Qnp upada, trend Qvk pa, razen na postaji Čatež, narašča. Pritoka Medija in Mirna imata trend Qsr le blago padajoč, Sotla pa celo naraščajoč. Naraščanje trenda Qsr sicer ni tako izjemno kot na Polskavi (17,6 \%), vendar je toliko bolj zanimivo, saj ima padavinska postaja Senovica v povirnem delu Sotle izrazito padajoč trend.

Ostale obravnavane padavinske postaje spodnjega Posavja imajo naraščajoč trend, prav tako pa tudi postaja podzemne vode na Krškem polju.

$\mathrm{V}$ porečju Save bi lahko med območja $\mathrm{z}$ dejanskim prekomernim zmanjševanjem količin vode uvrstili le povirno območje oziroma območje zgornjega toka Save.

\subsection{Porečje Ljubljanice}

Določitev površine porečja Ljubljanice je problematično, saj je potek razvodnic vprašljiv. Vodomerna postaja na Ljubljanici je v Mostah, tako da so v podatkih o pretokih upoštevani vse značilnosti spreminjajoče se kraške reke. Qsr ima v Mostah zmerno padajoč trend, upada pa tudi trend Qnp in Qvk. Pritoka Šujica in Cerkniščica pa imata izreden upad trenda Qsr, kar nad $30 \%$ in na Cerkniščici ima padajoč trend poleg Qnp tudi Qvk. Padavinskih postaj z dovolj dolgim nizom na porečju ni veliko, tako lahko le na podlagi treh postaj ugotovimo podpovprečno padajoč trend padavin. Za celo porečje je torej značilno zmerno zmanjševanje količin vode. 


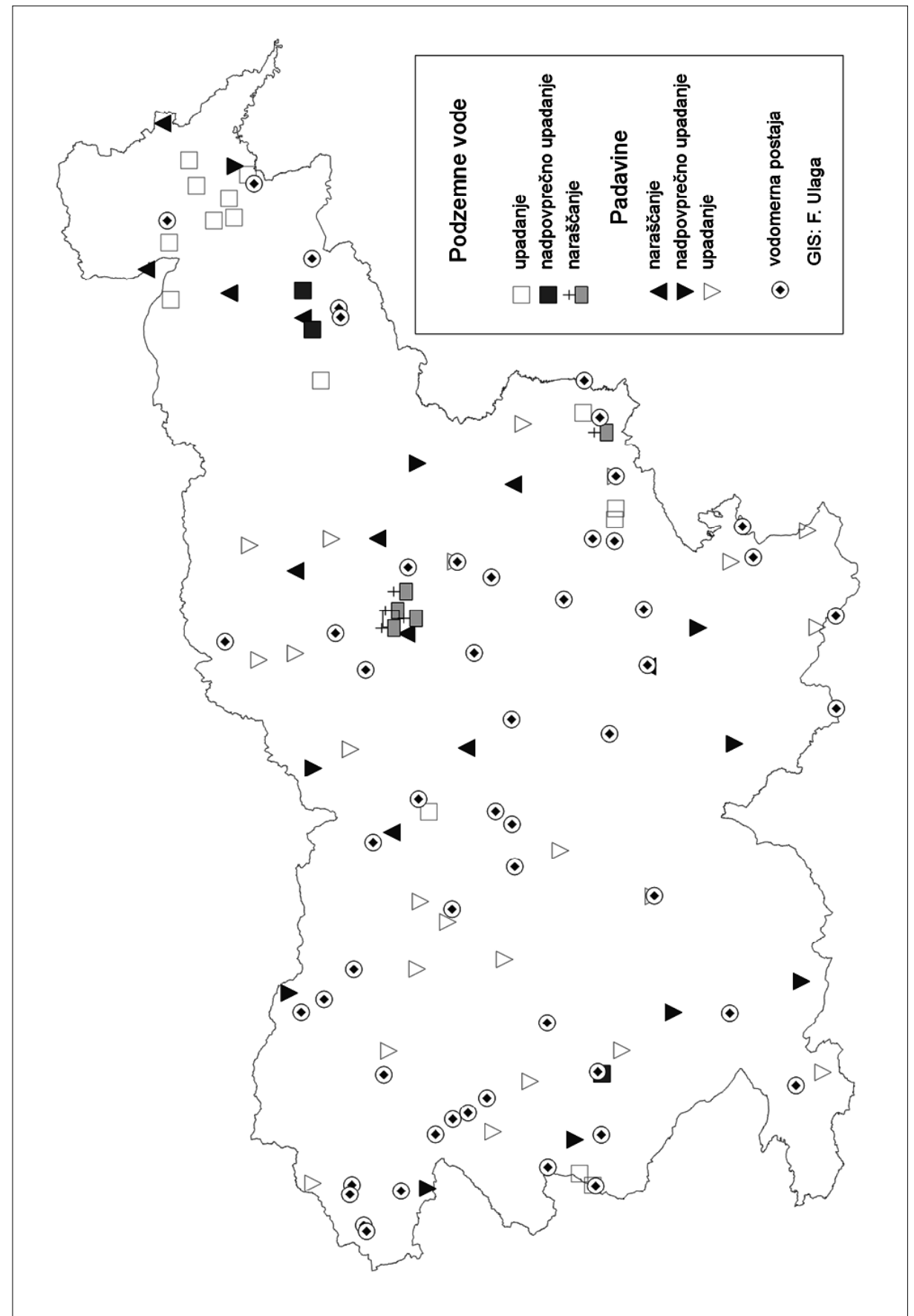

Slika 3: Spreminjanje trenda letnih količin padavin in podzemnih voda 108 


\subsection{Porečje Savinje}

Porečje Savinje je, glede na pričakovane spremembe trendov pretokov rek, najbolj tipično. Blag do zmeren upad Qsr, upadanje Qnp in precejšnje naraščanje Qvk so odraz tudi hudourniškega značaja reke. Zgornji tok in pritoki imajo močnejši trend upada Qsr in tudi trend padavin je v povirnem delu precejšen. V spodnji savinjski dolini pa je trend količine padavin naraščajoč in tudi gladina podtalnice blaga narašča oziroma ostaja nespremenjena. V primeru porečja Savinje lahko tako o nadpovprečnem zmanjševanju količine vode govorimo le v zaledju vodmerne postaje Levec na Ložnici.

\subsection{Porečje Krke}

Krka ima v zgornjem toku na postaji Podbukovje izredno padajoč trend Qsr, v srednjem in spodnjem toku pa povprečno upadanje trenda Qsr. Trend Qnp je na vseh štirih postajah reke padajoč, Qvk pa naraščajoč, razen na postaji Podbočje, kjer je tudi trend Qvk padajoč. Padavine na vseh padavinskih postajah porečja imajo povprečno padajoč trend in tudi gladina podtalnice Šentjernejskega polja povprečno upada. Izjema je le padavinska postaja Dvor, kjer je trend padavin zmerno naraščajoč in tudi trend Qvk na vodomerni postaji Dvor izkazuje večje naraščanje. Qsr te postaje ima le zmerno padajoč trend. Pritok Prečna ima podobne značilnosti spreminjanja vodnih količin v strugi kot Krka na vodomerni postaji Dvor, reka Radulja pa ima celo zelo blag upad trenda Qsr. Za celo porečje je torej značilno zmerno zmanjševanje količin vode, večji upad Qsr v povirnem delu Krke pa je morda tudi odraz vprašljive razmejitve vodozbirnega zaledja.

\subsection{Pokolpje}

Porečje Kolpe ima zmeren in povprečen upad trenda Qsr, razen v zgornjem toku pa poleg padajočega trenda Qnp še upadanje trenda Qvk. Pritok Lahinja ima nadpovprečen upad trenda Qsr. Padavine na vseh postajah imajo padajoč trend, v srednjem delu porečja pa je upadanje celo nadpovprečno. Za Pokolpje lahko torej ugotovimo, da gre za dejansko upadanje količin vode.

\subsection{Posočje}

Trend upadanja Qsr reke Soče je povprečen, trend Qnp upada, trend Qvk pa narašča. Pritok Koritnica ima trend upadanja Qsr nadpovprečen, upada pa tudi trend Qvk. Prav takšno spreminjanje pretokov lahko zasledimo tudi na vodo- 
merni postaji Log Čezsoški, po sotočju Koritnice in Soče. Padajoč trend Qvk imajo tudi ostali pritoki: Učja, Idrijca v Hotešku, Trebuša in Vipava. Nadpovprečen upad trenda Qsr ima Vipava $v$ zgornjem toku, kar izreden pa Idrijca, prav tako v zgornjem toku. Padavine v celotnem Posočju imajo padajoč trend, na visokih kraških planotah pa celo nadpovprečen upad. Prav tako ima padajoč trend gladina podtalnice, predvsem v Vipavski dolini, kjer pa velja omeniti tudi večje območje melioriranih površin. V celotnem Posočju se torej količina vode dejansko zmanjšuje, največji upad pa opazimo v Vipavski dolini, ki je zaradi kmetijskih površin še bolj občutljiva na vplive klimatskih sprememb.

\subsection{Jadransko povodje}

Reki Reka in Rižana imata trend upadanja Qsr nadpovprečen, padajoč trend pa ima tudi Qvk in Qnp na Rižani. Trend Qnp na Reki je celo naraščajoč, kar je verjetno posledica zadrževalnikov zgrajenih gorvodno od vodomerne postaje. Trend padavin v porečju Reke je nadpovprečno padajoč, na postaji Movraž pa le blago upada. Količina vode v porečju Reke torej res upada, v porečju Rižane pa morda lahko izredno zmanjševanje trenda Qsr pripišemo tudi melioriranim površinam in vodni oskrbi.

Regionalno gledano, bi lahko tudi za spreminjanje trendov količine vode ugotovili podobno, kot za ostale geografske dejavnike: regionalna raznolikost in raznolikost $\mathrm{v}$ smeri zahod - vzhod. Razvidna je povezanost in stopnja odvisnosti med elementi vodnega kroga. Količina padavin se zmanjšuje od zahoda proti vzhodu, pretoki rek prav tako in isto lahko trdimo za odtočne količnike porečij. Trend upadanja vodnih količin $\mathrm{v}$ pokrajini je najbolj intenziven $\mathrm{v}$ gorati zahodni, južni in severni Sloveniji, v vzhodnem in severovzhodnem delu pa je spreminjanje skoraj neopazno. Osrednja Slovenija je prehodno območje. Omeniti pa velja, da je najboljše ujemanje upadanja pretokov in padavin opaziti na porečju Kolpe in Vipave, največje neskladje pa v porečju Ljubljanice in Rižane.

To dejstvo nas kaj hitro vzpodbudi $\mathrm{k}$ razmišljanjem o večji odvisnosti pretokov rek od količine padavin v primeru manjše količine vode znotraj vodnega kroga. Vendar pa za takšne trditve nimamo dovolj empiričnih podatkov. $\mathrm{Ob}$ upoštevanju ostalih pokrajinskih komponent lahko razberemo, da je vpliv razgibanosti terena, nadmorske višine, poraščenosti z gozdom, in količine podtalnih zalog vode, dovolj intenziven, da za presojo dejanske količine razpoložljive vode, ne upoštevamo le podatkov o količini padavin znotraj nekega porečja. Presoja vplivov na vodne količine je kompleksna naloga, ki terja povezovanje številnih raziskovalnih strok. Za čim boljše vrednotenje podatkov pa je potrebno dobro delovno orodje, ki ga lahko poimenujemo tudi GIS - geografski 
informacijski sistem. »GIS teži $\mathrm{k}$ zbiranju podatkov iz realnega sveta $\mathrm{z}$ namenom, da bi obdelali in primerjali vrsto socialno - ekonomskih, ekoloških in zemljiških dejavnikov.« (Kvamme, 1997, str.19).

\section{ZAKLJUČEK}

Pri analiziranju trendov spreminjanja pretokov na izbranih vodomernih postajah hidrološke mreže ARSO, sem prišla do potrditve znane pokrajinske raznolikosti Slovenije. Ob primerjavi izrisanih trendnih linij 45 letnega obdobja, so se pokazale regionalne razlike predvsem pri trendih visokih konic in nizkih povprečij pretokov. Srednji obdobni pretoki imajo praktično na vseh vodomernih postajah, razen na Sotli in Polskavi, padajoč trend, kar je zanimivo predvsem $z$ vidika vodne bilance. Vendar kljub pomislekom ob splošnem zmanjševanju vodnih zalog stanje ni zaskrbljujoče. Večje pozornosti bi bili ob nadaljnji analizi gotovo deležni trendi spreminjanja nizko vodnih stanj, saj je zmanjševanje vode $\mathrm{v}$ sušnem delu leta predvsem $\mathrm{v}$ ravninskih kmetijskih pokrajinah, problem, ki presega reševanje morebitne škode le na regionalnem nivoju. Vendar pa lahko ob izkazanih trendih spreminjanja nizkih povprečij pretokov povem, da se pokaže intenzivnejše upadanje nizke vode le v primeru večjih, bolj vodnatih rek, medtem, ko imajo ravninski vodotoki, ki oskrbujejo $\mathrm{z}$ vodo večje strnjene kmetijske površine, trend skoraj nespremenljiv, ali rahlo naraščajoč.

Za večjo zanesljivost ugotovljenih trendov bi nedvomno potrebovali več podatkov in predvsem daljši opazovalni niz. Spremembe v pokrajini potekajo povsem različno hitro in s hidrološkega vidika, bi lahko marsikateri pokrajinski dejavnik povzeli kot konstanto. Ne pa seveda vseh. Za presojo spreminjanja dejanskih količin vode $\mathrm{v}$ izbranem porečju, moramo upoštevati poleg klimatskih sprememb tudi vpliv evapotranspiracije, poraščenosti z gozdom, količin podtalnih zalog vode, spreminjanje naravnih površin v kmetijska in urbana območja. Dejstvo, da se je povprečna letna temperatura zraka v Sloveniji povečala $\mathrm{v} 45$ letih za približno $0,8{ }^{\circ} \mathrm{C}$ in da je proces zaraščanja močno opazen, predvsem v zahodni Sloveniji, nas opozori na upoštevanje evapotranspiracije pri interpretaciji trendnih linij spreminjanja količine razpoložljive vode $\mathrm{v}$ naravi. Upad gladin podzemnih voda je na večini aluvialnih vodonosnikov majhen. Tu je shranjenih $70 \%$ zalog pitne vode, katerih natančne količine je seveda težko izmeriti. Skrb za prihodnost se tako, kljub upadanju srednjih letnih pretokov rek ne nanaša toliko na pomanjkanje vode, kot predvsem na njeno kakovost, zlasti $v$ sušnih mesecih leta.

$\mathrm{Na}$ koncu naj navedem le še nekaj dejstev, ki bi verjetno dobljene rezultate dodatno postavili na pravo mesto. Za analizo podatkov velja, da je obrav- 
navano leto šteto kot koledarsko in ne hidrološko oziroma meteorološko leto, ki se začenja septembra, torej pred nastopom jesenskih padavin in visokih pretokov rek. Če bi za analizo uporabili na takšen način združene podatke, bi gotovo lažje ugotavljali potek spreminjanja pretokov v daljšem obdobju in tudi s pomočjo snežne retinence, ki je prisotna na mnogih vodotokih, bi bolj natančno opredeljevali spremembe vodnih stanj.

\section{Literatura:}

Arhiv Agencije Republike Slovenije za okolje.

Brilly, M., 1992. Osnove hidrologije. Univerza v Ljubljani, FGG.

Gams, I., 1998. Lega Slovenije v Evropi in med njenimi makroregijami, Relief. Geografija Slovenije. Ljubljana, Slovenska matica.

Kolbezen, M., Pristov, J., 1998. Površinski vodotoki in vodna bilanca Slovenije. Ljubljana. MOP-HMZ RS.

Kvamme, K., Oštir - Sedej, K., Stančič, Z., Šumrada, R., 1997. Geografski informacijski sistemi. Ljubljana. ZRC SAZU.

Rodda, J.C., 1985. Facets of Hydrology II. Wallingford. Institute of Hydrology.

WMO, 1989. Guide to Hydrological Practices. Geneva.

\section{TRENDS IN DISCHARGE CHANGES OF SLOVENIAN RIVERS}

\section{Summary}

In view of hydrology, time plays one of the most important roles in analysing hydrological situations. In certain cases, a mere few seconds are crucial for a change to occur, while in other situations, thousands of years might be necessary. The average hydrological time for surface streams amounts to about 10 to 60 days, over which time the inflow and outflow of a certain area get balanced. The time required for the drainage of a certain river basin depends on the speed of the water-stream in the riverbed and the runoff speed in its catchment area, i.e. in the entire contributing area.

The trends in discharge changes result from the trends in hydrological conditions in a longer observation period. Considering the climatic changes, we estimated that mainly the extreme hydrological conditions were changing. Moreover, our interest was also focused on trends, increasing or decreasing, in 
the mean annual discharges at the selected river profiles, and on the differences in trends in Slovenia in general.

Linear trends in discharges were specified for available observation periods at the selected gauging stations. The analysis of archival data, obtained from the Agency of the Republic of Slovenia for the Environment for the 1955-99 period, was made for the mean annual values, Qsr, annual average of minimum low discharges, Qnp, and the annual extreme of maximum high discharges, Qvk. For the 45-year sequence of data our assessment of the increasing extremes has not been fully confirmed.

Of the 53 selected gauging stations, only 31 show a trend of decrease in the average minimum low discharges. However, as many as 19 gauging stations was registered the extreme in minimum low discharges of the period during the last eight years of the studied period (at eight stations in 1993). The deviation from the mean value of the period thus increased which indicates the decreasing trend. It should be noted that the decreasing trend of low average discharges is very mild, and at 20 gauging stations it was practically unchanged. There are but two exceptions among the selected gauging stations, those on the rivers of Dravinja and Reka where low discharges show the increasing trend. The annual extremes of high discharges also show the decreasing trend at 24 gauging stations. A trend of greater increase is present on the rivers of Dravinja, Savinja, Sava, Sotla, Kolpa, Krka and Soča. The catchment areas of the gauging stations with the increasing threat of floods cover $26 \%$ of the discussed area, or $21 \%$ of the territory of Slovenia.

Mean discharges, too, show the decreasing trend at all the selected gauging stations, except for those on the Polskava and the Sotla. The average decrease in mean annual discharges at the analysed gauging stations, whose catchment areas cover $17,910.5 \mathrm{sq} \mathrm{km}$, amounted to as many as $18.2 \%$ over the period of 45 years. An approximately average decrease was registered at 14 gauging stations. The above-average decrease was registered at 20 gauging stations, including all the stations on the Sava, while the below-average decrease was most explicit on the Kolpa and the Savinja.

On comparing the trend lines of mean annual discharges and the annual precipitation amounts at the selected 44 weather stations, I have come to a conclusion that, over a longer period, changes in precipitation do not always coincide with the trends in water quantities in riverbeds. At 11 weather stations, precipitation amounts were increased by $4.8 \%$ on average. On other gauging stations the precipitation amount decreased by $11.2 \%$ on average. The closest correspondence of decreases in discharges and precipitation was registered in the river basins of the Kolpa and the Vipava, while the greatest disparity was in the Ljubljanica river basin. 
The fact that the average annual air temperature in Slovenia has increased by about $0.8^{\circ} \mathrm{C}$ in 45 years and that the forest areas have evidently expanded, mainly in the western part of the country, points out that evapotranspiration should also be taken into account in interpreting the trend lines of changes in the amounts of available water in nature. The drop in water tables in most of the alluvial aquifers is not as strong as we have expected. $70 \%$ of drinking water reserves are stored there, whose exact quantities are very difficult to assess. In spite of the decreasing mean annual discharges the lack of water in the future is not as alarming as is the quality of water, especially in the dry months of the year. 